\title{
ПІДГОТОВКА ВЧИТЕЛІВ ТЕХНІКИ ТА ІНФОРМАТИКИ В УМОВАХ РЕФОРМУВАННЯ СИСТЕМИ ОСВІТИ: ПОЛЬСЬКИЙ ДОСВІД
}

Сучасна система освіти в Польщі перебуває на етапі модернізащії, спрямованого на вдосконалення й організацію діяльності шкіл різних типів. Приєднання до Болонського проиесу (1999 р.); приєднання до Брюгге Копенгагенського процесу (2004 р.) є початком реалізачії на державному рівні виконання стратегічних иілей, які відображають загальноєвропейську політику розвитку освіти на всіх рівнях. Головне завдання перетворень в освіті - наближення ї̈ до тих приничиів, які характерні для країн Свропейського Союзу. У статті розглядаються питання особливостей підготовки майбутніх вчителів техніки і інформатики у республічі Польща. Проаналізований досвід вітчизняних $і$ польських дослідників щзодо якісної підготовки майбутніх вчителів техніки і інформатики у Польщі. У ХХІ столітті інформація стала важливим стратегічним ресурсом, без використання якого не існує жодна краӥна світу. В ажливу роль відіграє професійна підготовка і професійна компетентність фахівия інформатики, шо є не тільки гарантією високого рівня інформаційної культури учнів і молоді, а й запорукою впровадження нових інформаційних технологій у всі сфери діяльності суспільства. В статті наголошується, що навчання майбутніх фахівиів потребує від учителів кваліфікованої підготовки, фах яких відрізнятиметься від попередньої підготовки. В статті акцентовано, що у Польщі велика увага приділяється інформатичному навчанню вчителів, які в майбутньому формуватимуть нове покоління, передаючи не тільки вміння зі своєї предметної галузі, а, насамперед, формуючи ставлення до життя і світу, в якому інформаційні технології відіграють важливу роль. Тому в інформачійному навчанні вчителів формування професійної компетенції має вирішальне значення. У підготовиі фахівців визначені певні види інформатичної компетениіі: володіння комп 'ютером як інтелектуальним інструментом; навчання за допомогою комп'ютера; використання комп'ютера в управлінні освітою. Доведено, щзо підготовки вчителів техніки та інформатики у Польщі спонукає до аналізу реформування освіти й виокремлення нових вимог до підготовки вчителя техніки та інформатики.

Ключові слова: учитель техніки та інформатики, реформування освіти, фахова підготовка, європейський досвід, компетениії.

Зміни в польській і європейській системах освіти, соціальній, культурній та економічній сферах ставлять перед учнями нові виклики й завдання, на що слід зважати в системі освіти України, ііі цілях, змісті та методах роботи. Реформи системи польської освіти вможливили загальне поліпшення показників навчання. У нових освітніх парадигмах змінюється також і фаховий профіль учителя, зв’язаний із його функціюванням у процесі навчання. Навчання майбутніх фахівців потребує від учителів кваліфікованої підготовки, фах яких відрізнятиметься від попередньої підготовки.

У “Стратегії розвитку освіти до 2020 року” серед напрямів, запланованих польськими педагогами, виокремлено: інтенсифікація процесу, названого інформаційним вибухом (одним з основних завдань школи $\epsilon$ формування в дітей і молоді вміння панувати над величезним потоком інформації, обирати іiі, розуміти, зберігати й використовувати); зростання ролі науки, а саме кількості різних науково-дослідних закладів, а також людей, які працюватимуть у них; пожвавлення міжнародних контактів, із чим зв'язане обов'язкове вивчення іноземних мов, вільне володіння інформаційними технологіями, а також історії, географії та звичаїв інших народів, 30 віддалених із географічного погляду (що, беззаперечно, впливатиме на інтеграційні процеси); поширення різноманітних цінностей і переконань, уникнення виявів ксенофобії, нетолерантності; школа повинна вчити дітей і молодь шанувати флору й фауну, служити тим, хто потребує допомоги; зберігати природні багатства, поважати традиційні ідеали правди й добра, зосередити свої зусилля не лише на дидактичній, а також на опікунській і виховній діяльності [2].

Мета реформ, які відбулися в Польщі, полягала в підвищенні загального рівня освіти в суспільстві, розширенні можливостей здобуття освіти для громадян і поліпшенні якості й “справедливості” системи освіти. Проведення реформ планувалося на кілька років. Зміни сталися як у структурі польської системи освіти, програмах навчання, так і в доведенні навчальних закладів до європейських стандартів, зокрема в руслі комп’ютеризації освіти. Наслідком досконалих змін повинно бути збільшення кількості молодих людей із середньою та вищою освітою [2]. Випускники польських шкіл мають здобувати широкопрофільну підготовку, де особлива увага зосереджена на інформатиці, мультимедіатехнологіях, дистанційному навчання, іноземній мові. Реформи системи польської освіти вможливили загальне поліпшення показників навчання.

Аналіз вітчизняних та зарубіжних педагогічних джерел свідчить, що проблема підготовки майбутнього вчителя в галузі інформатичних технологій постійно знаходиться в центрі уваги як вітчизняних, так і закордонних дослідників. Зокрема, польські вчені активно працюють над пошуком оптимальних шляхів удосконалення системи підготовки вчителів техніки та інформатики у закладах вищої освіти (ЗВО). Проблему підготовки майбутніх учителів техніки та інформатики початкових класів досліджували українські вчені А. Вихрущ, I. Гевко, В. Гусєв, Й. Гушулей, А. Дьомін, М. Жиделєв, В. Ледньов, В. Мадзігон, В. Сидоренко, М. Скаткін, Г. Терещук, Д. Тхоржевський, П. Яковишин та ін.) $[1,6]$. Теоретико-методичні та практичні основи формування 
інформатичних компетентностей підготовки майбутніх вчителів початкових класів в Україні відображені у працях В. Барановської, С. Бикова, А. Коломієць, Н. Морзе, Н. Насирової, Л. Пєтухової, Ю. Рамського, О. Спіріна, О. Шиман та інших. Усі дослідники відмічають, що важливою ознакою розвитку освіти ХXI століття $є$ інтеграційні процеси в країнах Свропи, спрямовані на формування єдиної, ефективної системи професійної підготовки, покликаної готувати вчителівтехніки та інформатики, здатних функціонувати у швидкозмінних умовах сучасного ринку праці з його високими вимогами до рівня професіоналізму та фахової майстерності. Професійна підготовка вчителів техніки та інформатики спрямована передусім на формування фахівців 3 новітнім типом мислення, котрі сприймають швидкозмінні соціально-економічні, технологічні та інформаційні реалії навколишнього світу та інформаційного світогляду, заснованого на розумінні визначальної ролі інформації та інформаційних процесів у різних сферах людської діяльності [1].

Як наголошує М. Лєлонек (M. Lelonek), нині в Польщі у підготовці вчителів інформатики можна окреслити два ступені навчання: перший на рівні трирічних професійних навчань (ліценціати) і другий на рівні дворічних доповнювальних магістерських навчань [7].

Memoю cmammi є дослідження досвіду Республіки Польща в галузі підготовки майбутнього вчителя техніки та інформатики, аналіз проблем реформування системи освіти в європейському контексті; пошук шляхів удосконалення інформатичної підготовки студентів - майбутніх вчителів техніки та інформатики.

Нині потрібний учитель, який щодня керується універсальними цінностями, компетентний професіонал, відкритий для потреб, очікувань і проблем учнів, критичний і відповідальний за свій розвиток, який невпинно вдосконалює свою кваліфікацію, вільно володіє інформаційними технологіями. Бажано, щоб одночасно він був вдумливим практиком і дослідником освітньої діяльності, який уміє мислити категоріями майбутнього. Такий учитель працює творчо, зорієнтований на інновації, ставиться до учня як до рівного, стимулює розвиток його інтелектуальних здібностей, орієнтує школяра в просторі знань, готує до самоосвіти й самоконтролю, відповідальний, піклується про постійний ріст своєї професійної кваліфікації.

Реформи, що відбулися в польській освіті, спонукають учителів до рефлексії сучасних засобів навчання, а також до пошуку нових, якісно кращих методів роботи. Підготовка вчителів до здійснення новітніх ідей та освітніх завдань починається із професійної підготовки та являє собою неперервний процес.

У Республіці Польща розвиток інформатизації шкільної освіти регламентовано низкою документів на рівні Свропейського Союзу, а також нормативно-правовими актами державного значення. Програмами та Резолюціями Європейської Ради та Європарламенту “Освіта і Навчання 2010”, “Загальноєвропейські принципи компетенцій і кваліфікації вчителів" (2004), “Навчання протягом усього життя” (2006), “Ключові компетенції для навчання протягом усього життя” (2006) надано рекомендації щодо європейської перспективи розвитку освітніх систем держав-членів Співтовариства. Програмою польського уряду “Стратегія Розвитку Людського Капіталу 2020” з метою “підвищення рівня компетентності та кваліфікації громадян і поширення використання цифрових інструментів в галузі освіти та професійної підготовки” визначені заходи щодо підвищення кваліфікації вчителів для застосування інтерактивних методів навчання у викладанні всіх предметів, а не тільки інформатичних дисциплін, розробки якісних електронних навчальних матеріалів, планів уроків і широкого впровадження е-підручників, забезпечення відповідного шкільного обладнання (ноутбуків, інтерактивних дошок, проекторів тощо) для широкого впровадження IКТ в освітньому процесі (Strategia Rozwoju, 2013, c. 57-58). Базовими законодавчими документами інформатизації шкільної освіти державного рівня у Польщі є: Закон про освіту (1991) та Закон про зміни до Закону про освіту (2013), Постано ва Міністерства освіти про Основний навчальний план дошкільної освіти та загальної освіти у визначених типах шкіл (2012), Постанова Ради Міністрів про умови, форми і процедури реалізації проекту з підвищення компетентності вчителів та учнів у галузі інформаційно-комунікаційних технологій (2012). Постановою Міністерства освіти Польщі (2014 p.) (Dz.U. Poz. 909) конкретизовано й систематизовано вимоги до шкільного е-підручника, регламентовано його зміст і структуру. Загалом нормативно-правова база щодо інформатизації шкільної освіти у Республіці Польща регулярно поновлюється. Рада з питань інформатизації освіти при Міністерстві освіти Польщі координує проведення заходів 3 широкого впровадження ІКТ в шкільний освітній процес. Варто зауважити, що Міністерство освіти Польщі опікується питаннями лише шкільної освіти, заклади вищої освіти підпорядковані Міністерству науки і вищої освіти Польщі.

Навчання учителів у вищих педагогічних школах у період модернізації освіти тісно зв'язане з розвитком науки педевтології. У польській педагогічній теорії та в педевтології сформовано кілька основних концепцій підготовки майбутніх учителів [8].

Перша концепція зважає на потребу в забезпеченні вчителів максимально широкими загальними знаннями, що гармонує з положеннями енциклопедичної освіти стосовно необхідності набуття широкої системи знань і панівної ролі вчителя як особливого джерела знань учнів.

Друга концепція, популяризуючи спеціальне навчання, утверджує принцип, що хороший учитель - це особистість, яка має фундаментальні знання з певної навчальної дисципліни: математики, фізики, польської мови (польської філологіï), біології тощо.

Третя концепція відображає пріоритетність методичної підготовки майбутніх учителів, необхідної для щоденної професійної діяльності. Успішність діяльності вчителя, як вважають прихильники цієї концепції, зумовлена вміннями вільно використовувати знання на практиці. Четверта проблемна (прогресивна) 
концепція передбачає, що підготовка вчителя потребує передусім опанування ним способів спостереження, окреслення й розв’язання різноманітних життєвих проблем, зокрема й освітніх [1].

Новим аспектом в навчанні вчителів техніки у дев'яностих роках XX ст. і на початку XXI ст. були так звані спеціальності технічного виховання. Визначали їх самі ж навчальні заклади в межах наданих їм повноважень. Необхідність створення цих спеціальностей у початковій стадії їх формування виникала, головним чином, через відсутність підготовки вчителів до проведення занять в галузі технічної освіти та пов'язані 3 цим труднощі забезпечення необхідних годин навчального навантаження для відповідного дидактичного рівня. Пізніше ці спеціальності мали дати вчителям технічного виховання додаткові можливості для працевлаштування в різних типах установ, окрім шкіл. Таким чином, на кінець дев'яностих років XX ст. 3ВО здійснювали підготовку вчителів техніки за 26 спеціальностями [9].

Після кількох років впровадження, новий проведений аналіз всіх реалізованих спеціальностей у рамках напряму “технічне виховання” довів, що в період 2001-2002 академічного року в університетах, політехніках, академіях та вищій педагогічній школі підготовку фахівців здійснювали більш як за 30 різними спеціальностями [6, с. 35-41]. Кожен із 14 вишів у Польщі, що готували вчителів техніки, реалізував інші спеціальності. Іноді вони були мало, або й взагалі не пов'язані з навчальним предметом “техніка” у загальноосвітніх і початкових школах, у гімназіях. Вивчення проблеми довело, що з жодного іншого напряму навчання у Польщі не було так великої різнорідності спеціальностей, як у технічному вихованні.

Запровадження навчання за спеціальностями, які мають мало спільного з напрямом підготовки “технічне виховання”, з самого початку викликало багато сумнівів і дискусій серед фахівців даної галузі освіти. Проте в умовах ринкової економіки, найліпшим випробуванням є саме життя [5].

Технології цифрової обробки, передачі та зберігання інформації вдосконалюються і поширюються щораз швидше. Їх використання не оминає і школу. Система освіти асимілює їх повільно і нерівномірно, але постійно. Незважаючи розвиток персональних комп'ютерів упродовж чверті століття, їх щораз більший вплив на різні галузі господарювання, виникнення великої кількості мобільних варіантів, як і раніше, комп'ютер вважається у школі технічною новинко, суперечливим інструментом або навіть загрозою для педагогіки. Часто межі його застосування в школі обмежуються комп'ютерним класом і обсягом спеціалізованих курсів в області інформаційних технологій (IT). Незважаючи на це, працівники освітньої галузі усвідомлюють важливість комп'ютерної грамотності, створюють і планують використання педагогічного програмного забезпечення, використання ресурсів мережі Інтернет. Відповідно, вчителі не лише навчають, але й самі навчаються використанню комп’ютерів, програмного забезпечення і мереж. Від володіння необхідними навичками залежить професійне зростання викладачів, реалізація планів щодо універсальної й обов’язкової системи сертифікації [4].

У сьогоднішньому мінливому світі ЗВО повинен готувати студентів як майбутніх педагогів так, щоб вони могли знайти своє застосування на ринку праці. Ця місія не повинна вступати у суперечність із завданнями школи і навчальних предметів. Тому викладачам вищих навчальних закладів потрібно постійно слідкувати за тим, які вимоги висуває ринок праці, як ці вимоги будуть змінюватися у майбутньому.

Сучасний ринок праці вимагає вміння користуватися комп'ютером та Інтернетом, адже суспільство вже давно визнало цифрову грамотність одним з основних умінь, на рівні з письмом, читання і лічбою [10]. Ці навички необхідні на ринку праці, проте їх рівень і обсяг є недостатніми.

Формування в студентів ключових комп'ютерних умінь не є основною метою освіти, це, швидше, перший крок для досягнення інших цілей, спосіб набуття учнями більш складних навичок, які необхідні молодій людині, що вступає в конкуренцію на ринку праці інформаційної ери.

У доповіді про розвиток людини В. Абрамович зазначає, що “глобальне інформаційне суспільство та електронна економіка будуть вимагати від працівників творчості, дисциплінованості, самостійності і вміння співпрацювати 3 іншими". Водночас 3 тим, він стверджує, що “ці функції не є цілями системи сучасної освіти. У школах і університетах вимагається швидше опанування існуючих знань, а не формування здатності використовувати їх і створювати нові знання" [1].

Варто задуматися над тим, в якому напрямі повинна змінюватися сучасна система освіти, щоб у процесі навчання студенти змогли здобули хорошу підготовку для участі та конкуренції на сучасному ринку праці. Якщо доповнити навчальний процес використанням інформаційних технологій для підвищення ефективності навчання, то слід розуміти цю ефективність не у покращенні оцінок, а у поліпшенні становища випускників на ринку праці [4]

Таким чином, сучасна ситуація ставить перед ЗВО завдання підготовки не просто фахівців конкретних галузей і спеціальностей, але й творчих, комунікативних, гнучких, готових до роботи у команді, Водночасчас незалежних працівників.

Упродовж останніх років в концепції вищої освіти і їі реалізації у різних вищих навчальних закладах відбулися значні зміни в підготовці вчителів. Наприклад, сьогодні існує рівень ліценціату та додаткове навчання після вищого професійного навчання як спеціальність 3 іншого напряму підготовки. Суттєві відмінності спостерігаються щодо набору студентів на цей напрям. У 1998-1999 навчальному році підготовка до технічного виховання як галузі досліджень чи спеціальності існувала у 16 3ВО, зокрема: у 3 університетах, у 6 педагогічних школах, у 8 технічних вищих школах. Детальніше це питання розкрито на рисунку 1. 
Окрім доповнення навчальних планів новими предметами, розроблення програм і модернізації змісту навчання, особливу увагу також приділено розвитку різноманітних довго-і короткотривалих форм професійної освіти вчителів.

У результаті дефіциту кадрів, який спостерігався у той період в освіті, виникло дещо парадоксальне явище, адже при працевлаштуванні вже не вимагалося наймати на роботу вчителя тільки 3 повною магістерською освітою. Натомість для всіх учителів було впроваджено вимогу щодо закінчення вищих курсів. Для початкових шкіл це могли бути навіть професійні ліценціацькі курси, відомі також як курси І ступеня. На зламі 2002-2003 років їх провадили більшість вищих навчальних закладів, а також вчительські колегії (як неповні вищі академічні навчальні заклади), але за умови, що контроль за ними вели університети, вищі педагогічні школи або політехніки, які мали право провадження повних магістерських студій [6].

Таким чином, після реформи 1999 року у системі освіти вчителів техніки прийнято ряд важливих постанов:

1. Підготовка вчителів загальнотехнічного напряму повинна враховувати потреби освіти, в тому числі предметів відповідного напряму. Відповідність реалізованого змісту протягом навчання з існуючими потребами викладання предметів, повинна бути однією з основних умов освіти в університетах і педагогічних академіях.

2. Вчителі техніки, які здобули вищу освіту, повинні володіти:

а) грунтовними технічними знаннями, пов'язаними з обраним напрямом навчання та предметами, які викладаються у школах;

б) здатність керувати процесом навчання учнів;

в) розуміння процесів, які відбуваються в сучасній школі, у відносинах основних соціальних груп, таких як студенти, вчителі, сім'я;

г) розуміння соціально-політичних явищ у контексті освітнього процесу.

3. Зберегти різноманітність вищих шкіл, які здійснюють підготовку вчителів техніки для початкових шкіл і гімназій. До них належать:

1) 6 університетів;

2) 5 політехнік;

3) 2 педагогічні академії;

4) 1 вища педагогічна школа.

Більшість 3 цих 14 ЗВО пропонують освіту на рівні п’ятирічних повних магістерських курсів або протягом трирічної ліценціатської освіти.

4. Зважаючи на рівень загального технічного курсу підготовки вчителів, визначено три рівні навчання:

1) повний п’ятирічний курс навчання для здобуття ступеня магістра;

2) трирічні курси вищої професійної освіти, що забезпечують ступінь бакалавра (ліценціата), які називають також І ступенем навчання;

3) дворічні магістерські доповнюючі курси, які називають також II ступенем, для осіб, що закінчили навчання за І ступенем. Їх можуть здійснювати тільки вищі навчальні заклади, ліцензовані надавати освітній рівень "магістр".

5. Вступ Польщі до Європейського Союзу й різні стандарти освіти вчителів техніки у цих країнах спричинили те, що розпочалося впровадження дворівневої підготовки вчителів цього напряму, тобто, спочатку трьохрічний ліценціат (ступінь бакалавр) а потім двохрічне доповнююче навчання на ступінь магістра. Модель такої підготовки, яку в загальному можна виразити як 3+2, вже входить до практики навчання вчителів техніки як обов'язкова [7].

Новим аспектом в навчанні вчителів техніки у дев'яностих роках XX ст. і на початку XXI ст. були так звані спеціальності технічного виховання. Визначали їх самі ж навчальні заклади в межах наданих їм повноважень. Необхідність створення цих спеціальностей у початковій стадії їх формування виникала, головним чином, через відсутність підготовки вчителів до проведення занять в галузі технічної освіти та пов'язані 3 цим труднощі забезпечення необхідних годин навчального навантаження для відповідного дидактичного рівня. Пізніше ці спеціальності мали дати вчителям технічного виховання додаткові можливості для працевлаштування в різних типах установ, окрім шкіл. Таким чином, на кінець дев'яностих років XX ст. 3ВО здійснювали підготовку вчителів техніки за 26 спеціальностями [7].

Після кількох років впровадження, новий проведений аналіз всіх реалізованих спеціальностей у рамках напряму “технічне виховання” довів, що в період 2001-2002 академічного року в університетах, політехніках, академіях та вищій педагогічній школі підготовку фахівців здійснювали більш як за 30 різними спеціальностями [3]. Кожен із 14 вишів у Польщі, що готували вчителів техніки, реалізував інші спеціальності. 
Іноді вони були мало, або й взагалі не пов’ язані з навчальним предметом “техніка” у загальноосвітніх і початкових школах, у гімназіях. Вивчення проблеми довело, що з жодного іншого напряму навчання у Польщі не було так великої різнорідності спеціальностей, як у технічному вихованні.

Запровадження навчання за спеціальностями, які мають мало спільного з напрямом підготовки “технічне виховання", з самого початку викликало багато сумнівів і дискусій серед фахівців даної галузі освіти. Проте в умовах ринкової економіки, найліпшим випробуванням є саме життя.

Питання підготовки майбутніх учителів техніки та інформатики у галузі інформаційно-комунікаційних технологій є одним із пріоритетних предметів вивчення та обміну досвідом у Республіці Польща протягом останніх років, зважаючи на впровадження болонських стандартів в освіту та науку. Адже, згідно з “Висновками Ради Свропейського Союзу та представників урядів країн-членів щодо удосконалення професійної підготовки вчителів", здатність використовувати інформаційно-комунікаційні технології для розв'язання різноманітних завдань, а також для власного безперервного професійного розвитку є однією із здатностей, які сучасний учитель має набути під час навчання у педагогічному закладі та у процесі подальшого професійного розвитку [3].

У Польщі Стандарти професійної підготовки вчителів прийняті Постановою міністра науки та вищої освіти від 17 січня 2012 року. У цьому документі наголошується, що кожен учитель повинен бути готовим використовувати інформаційні технології у власній діяльності та у навчально-виховному процесі.

У Стандартах підготовки вчителів Польської Республіки для роботи у сфері інформаційно-комунікаційних технологій зазначено, що “всі вчителі мають бути вчителями інформаційних технологій у тій мірі, що й учителями читання, письма і усного рахунку” [10].

Згідно зі стандартами підготовки вчителів, які діють в Польщі, кожен учитель для ефективної професійної діяльності повинен мати наступні інформатичні компетентності:

- використання понять (термінології), засобів, інструментів та методів ІКТ (учитель повинен знати будову та функції основних та периферійних засобів комп’ютера, вміти використовувати мультимедійні засоби для демонстрації мультимедійних матеріалів, послугуватися локальною мережею та сервісами мережі Інтернет; уміти здійснювати інсталяцію програмного забезпечення, необхідного для професійної діяльності; знати санітарно-гігієнічні вимоги до організації праці за комп'ютером; можливості застосування комп'ютера для організації діяльності школи та комунікації з батьками);

- ІКТ як компонент майстерності вчителя (учитель повинен уміти організовувати збереження електронної інформації; використовувати програмне забезпечення - текстовий, графічний редактор, табличний процесор та бази даних; уміти готувати мультимедійні презентації; володіти навичками застосування засобів мережі Інтернет для отримання інформації, обміну досвідом; використовувати комп'ютер як засіб для самонавчання та підвищення власної професійної майстерності);

- використання IКТ як освітнього середовища, відповідного до етапу та галузі навчання - планування та проектування середовища навчання, оцінка досягнень учнів;

- правові, етичні та суспільні аспекти доступу до ІКТ і використання цих технологій [9].

Польські вчителі з 2005 року беруть активну участь у проектах європейської освітньої програми еTwinning, що працює в структурі Фонду розвитку освіти Республіки Польща. Метою даної програми є об'єднання вчителів та налагодження співпраці серед шкіл європейських країн з використанням IКТ для взаємодії, обміну досвідом, інформацію, методичними та навчальними матеріалами. Під патронатом програми etwinning проводяться міжнародні навчальні семінари та конференції, курси електронного навчання та контактні семінари, де польські вчителі можуть зустрітися з колегами з інших країн і підписати угоду про співпрацю між школами. Вчителям пропонується пройти безкоштовне online-навчання по роботі із системою дистанційного навчання Moodle. Проекти програми eTwinning з використанням ІКТ охоплюють учасників 332 країн та сприяють співпраці вчителів об'єднаної Європи.

Висновок. У процесі освітньої реформи в Польщі для підготовки молоді до життя в інформаційному суспільстві впроваджують низку національних програм: “Національна програма розвитку інформаційної освіти” [7], “Інтернет для шкіл” [8] та ін., функціонують тривалі стратегії для Польщі на період до 2020 року.

3 огляду на значний досвід та позитивні результати Польщі в галузі залучення вчителів до освітніх програм та проектів, доцільним є зміна підходів щодо організації освітнього процесу для майбутніх педагогів України. Програма Intel - Навчання для майбутнього вичерпала себе 3 точки зору можливостей саморозвитку вчителів у галузі ІКТ.

\section{Використана література:}

1. Гевко І. В. Формування і розвиток професіоналізму вчителя технологій: теорія і методика. Кам'янець-Подільський: Аксіома, 2017.392 c.

2. Івашко О. А. Основні напрями та наслідки реформування системи освіти в республіці Польща в кінці XX - на початку XXI ст. Збірник наукових праць Бердянського державного педагогічного університету (Педагогічні науки). Бердянськ: БДПУ, 2010. № 4. С. 79-84

3. Мищишин I. Удосконалення професійної підготовки вчителів у Польщі в контексті інтеграційних змін. Вісник Львів. $y н-m y$. Сер. пед. 2005. Вип. 19. Ч. 1. С. 166-171.

4. Парламентські слухання "Реформи галузі інформаційно-комунікаційних технологій та розвиток інформаційного простору України” [Електронний ресурс]. - Режим доступу : http://gska2.rada.gov.ua/zakon/new/par_sl/SL030216.htm. 
5. Проблема формування інформатичних компетентностей майбутніх учителів початкових класів у педагогічній теоpiї [Електронний ресурс] Педагогічний дискурс. 2011. № 10. С. 29. Режим доступу : file:///C:/Users/User/Downloads/ peddysk $2011 \quad 10$ 7.pdf

6. Тхоржевський Д. О. Система трудового навчання. Київ: Рад. шк., 1975. 199 с.

7. Отчет о развитии образования в Польше. - [Електронний ресурс]. - Режим доступу : http://webcache.googleusercontent. $\mathrm{com} /$ search?q=cache:MFBEsVQA91sJ: www.edudemo.home.pl/biblioteka/gz/otchet.pdf $+\& \mathrm{~cd}=1 \& \mathrm{hl}=\mathrm{ru} \& \mathrm{ct}=\mathrm{clnk} \& \mathrm{gl}=\mathrm{ua}$

8. Conclusions of the Council and of the Representatives of the Governments of the Member States, meeting within the Council of 15 November 2007, on improving the quality of teacher education Europe / Official Journal of the European Communities, C 300/6 of 12.12.2007 [Електронний ресурс]. Режим доступу : http://eur-lex.europa.eu/LexUriServ/LexUriServ.do?uri =OJ:C :2007:300:0006:0009:EN:PDF

9. Ewaluacja ex-post rządowego programu rozwijania kompetencji uczniów i nauczycieli w zakresie stosowania technologii informacyjno-komunikacyjnych „Cyfrowa szkoła” [Електронний ресурс]. Режим доступу : http://eduentuzjasci.pl/images/ stories/publikacje/ibe-raport-cyfrowa-szkola.pdf.

10. Fundacja Nowoczesna Polska [Електронний ресурс]. Режим доступу : http://nowoczesnapolska.org.pl.

11. Proponowane kierunki rozwoju społeczeństwa informacyjnego w Polsce do 2020 r. [Електронний ресурс]. Режим доступу : http://www.nauka.gov.p1/g2/oryginal/2013_05/5de4e12caa5c43f9e7ad159505c26e03.pdf.

12. Standardy przygotowania nauczycieli w zakresie technologii informacyjnej i informatyki [Електронний ресурс]. Режим доступу : http://www.if.univ.rzeszow.pl/spk_if/pliki/standardy.pdf.

\section{References:}

1. Hevko I. V. Formuvannia i rozvytok profesionalizmu vchytelia tekhnolohii: teoriia i metodyka. Kamianets-Podilskyi: Aksioma, 2017. $392 \mathrm{~s}$.

2. Ivashko O. A. Osnovni napriamy ta naslidky reformuvannia systemy osvity v respublitsi Polshcha v kintsi KhKh - na pochatku KhKhI st. Zbirnyk naukovykh prats Berdianskoho derzhavnoho pedahohichnoho universytetu (Pedahohichni nauky). - Berdiansk: BDPU, 2010. - № 4.- S. 79-84

3. Myshchyshyn I. Udoskonalennia profesiinoi pidhotovky vchyteliv u Polshchi v konteksti intehratsiinykh zmin. Visnyk Lviv. un-tu. Cer. ped. 2005. Vyp. 19. Ch. 1. S. 166-171.

4. Parlamentski slukhannia "Reformy haluzi informatsiino-komunikatsiinykh tekhnolohii ta rozvytok informatsiinoho prostoru Ukrainy" [Elektronnyi resurs]. Rezhym dostupu: http://gska2.rada.gov.ua/zakon/new/par_sl/SL030216.htm.

5. Problema formuvannia informatychnykh kompetentnostei maibutnikh uchyteliv pochatkovykh klasiv u pedahohichnii teorii [Elektronnyi resurs] Pedahohichnyi dyskurs. - 2011. - № 10. S. 29. Rezhym dostupu: file://C:/Users/User/Downloads/ peddysk_2011_10_7.pdf

6. Tkhorzhevskyi D. O. Systema trudovoho navchannia/ D. O.Tkhorzhevskyi. Kyiv : Rad. shk., 1975. $199 \mathrm{s.}$

7. Otchet o razvytyy obrazovanyia v Polshe. - [Elektronnyi resurs]. Rezhym dostupu: http://webcache.googleusercontent.com/

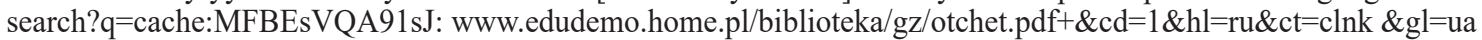

8. Conclusions of the Council and of the Representatives of the Governments of the Member States, meeting within the Council of 15 November 2007, on improving the quality of teacher education Europe / Official Journal of the European Communities, C 300/6 of 12.12.2007 [Elektronnyi resurs]. Rezhym dostupu: http://eur-lex.europa.eu/LexUriServ/LexUriServ.do?uri =OJ:C:200 7:300:0006:0009:EN:PDF

9. Ewaluacja ex-post rządowego programu rozwijania kompetencji uczniów i nauczycieli w zakresie stosowania technologii informacyjno-komunikacyjnych - „Cyfrowa szkoła” [Elektronnyi resurs]. Rezhym dostupu: http://eduentuzjasci.pl/images/ stories/publikacje/ibe-raport-cyfrowa-szkola.pdf.

10. Fundacja Nowoczesna Polska [Elektronnyi resurs]. Rezhym dostupu: http://nowoczesnapolska.org.pl.

11. Proponowane kierunki rozwoju społeczeństwa informacyjnego w Polsce do 2020 r. [Elektronnyi resurs]. Rezhym dostupu: http://www.nauka.gov.pl/g2/oryginal/2013 05/5de4e12caa5c43f9e7ad159505c26e03.pdf.

12. Standardy przygotowania nauczycieli w zakresie technologii informacyjnej i informatyki [Elektronnyi resurs]. Rezhym dostupu: http://www.if.univ.rzeszow.pl/spk_if/pliki/standardy.pdf.

13. Монько Р. М. Подготовка учителей техники и информатики в условиях реформирования системы образования: польский опыт.

Современная система образования в Польше находится на этапе модернизации, направленного на совершенствование и организачию деятельности школ различных типов. Присоединение к Болонскому проиессу (1999.) присоединения к Брюгzе Копенгагенского проиесса (2004.) является началом реализации на государственном уровне выполнения стратегических иелей, которые отражают общеевропейскую политику развития образования на всех уровнях. Главная задача реформирования в образовании - приближение ее к тем принципам, которые характерны для стран Европейского Союза. В статье рассматриваются вопросы особенностей подготовки будущих учителей техники и информатики в республике Польша. Проанализирован опыт отечественных и польских исследователей по качественной подготовке будущих учителей техники и информатики в Польше. В ХХІ веке информация стала важным стратегическим ресурсом, без использования которого не существует ни одна страна мира. Вважную роль играет профессиональная подготовка и профессиональная компетентность специалиста информатики, является не только гарантией высокого уровня информационной культуры учашихся и молодежи, но и залогом внедрения новых информационных технологий во все сферы деятельности общества. В статье отмечается, что обучение будущих специалистов требует от учителей квалифицированной подготовки, специальность которых будет отличаться от предварительной подготовки. В статье акцентировано, что в Польше большое внимание уделяется информатические обучению учителей, которые в будущем будут формировать новое поколение, передавая не только умение со своей предметной области, a, прежде всего, формируя отношение к жизни и мира, в котором информационные технологии играют важную роль. Поэтому в информационном обучении учителей формирования профессиональной компетенции имеет решающее значение. В подготовке специалистов определены основніе виды информатической компетенции: владение компьютером как интеллектуальным инструментом; обучение с помощью компьютера; использование компьютера в управлении 
образованием. Доказано, что подготовки учителей техники и информатики в Польше побуждает к анализу реформирования образования и выделения новых требований к подготовке учителя техники и информатики.

Ключевые слова: учитель техники и информатики, реформирования образования, профессиональная подготовка, европейский опьт, компетентности.

Monko R. M. Training of technical and informatics teachers in the reform of the education system: Polish experience

The current education system in Poland is in the process of modernization, aimed at improving and organizing the activities of schools of various types. Accession to the Bologna Process (1999); the accession to the Bruges Copenhagen Process (2004) is the beginning of the implementation at the national level of the implementation of strategic goals that reflect the panEuropean education development policy at all levels. The main task of transformations in education is to bring it closer to those principles that are characteristic of the countries of the European Union. The article deals with the peculiarities of the training of future teachers of engineering and computer science in the Republic of Poland. The experience of national and Polish researchers on qualitative training of future teachers of technology and computer science in Poland is analyzed. In the 21st century, information has become an important strategic resource, without which no country in the world exists. An important role is played by the professional training and professional competence of a specialist in computer science, which is not only a guarantee of a high level of information culture of students and young people, but also a guarantee of the introduction of new information technologies in all spheres of society. The article emphasizes that the training of future specialists requires teachers of qualified training, whose specialties will be different from the previous training. In the article it is emphasized that in Poland the great attention is paid to the informational training of teachers who will in the future form the next generation, transferring not only the skills in their subject area, but above all, shaping the attitude to life and the world in which information technologies play an important role. Therefore, the formation of professional competence in teachers' information training is crucial. Specialists' training defines certain types of informational competence: owning a computer as an intellectual tool; computer-based training; the use of a computer in educational management. It has been proven that the training of technical and computer science teachers in Poland leads to an analysis of education reform and the identification of new requirements for the training of technical and computer science teachers.

Key words: teacher of engineering and computer science, education reform, professional training, European experience, competences.

\author{
УДК 331.108 \\ DOI https://doi.org/10.31392/NPU-nc.series5.2020.72-2.09
}

Морозова М. E.

\title{
ПЕРСПЕКТИВИ РОЗВИТКУ УПРАВЛІННЯ ПЕРСОНАЛОМ ОРГАНІЗАЦІЇ
}

Професійний розвиток в сучасних умовах є важливим аспектом, щуо обумовлює необхідність постійних системних наукових досліджень. В умовах, щзо склалися в Украйні на нинішньому етапі, становлення проблеми професійного розвитку працівників та забезпечення умов для їх ефективного професійного зростання набула стратегічного значення, адже саме від иього залежить формування кадрового потенціалу організаиії в иілому. Отже, однією з найважливіших складових проиесу професійного розвитку є готовність самої людини професійно зростати. Розвиток персоналу - ие система взаємопов'язаних дій, елементами якої є: вироблення стратегії, прогнозування і планування потреби в кадрах тієї або іншої кваліфікації, управління кар'єрою і професійним ростом; організачія процесу адаптації, навчання, тренінгу, формування організаційної культури. Система розвитку персоналу організації включає сукупність елементів (методів, засобів, соиіальних інститутів), які, впливаючи на розвиток персоналу організачії, задають зміни його здібностей, адекватних потребам організації. У статті запропоновані: алгоритм розробки плану розвитку персоналу, модель професійного розвитку з орієнтацією на кар'єрне зростання, модель розвитку персоналу з орієнтацією на ключові компетениії, організація процесу розвитку персоналу, система розвитку персоналу на корпоративному рівні. Але слід назвати ті специфічні риси, які відрізняють навчання дорослих та є властивостями, характерними саме для періоду дорослості людини, які можуть впливати на процес активізації, розвитку та мати змогу бути корисними під час його професійного вдосконалення.

Ключові слова: розвиток персоналу, иілі і завдання розвитку, стратегія розвитку персоналу, система розвитку персоналу, мотивація персоналу, професійне навчання, конкурентоспроможність працівника.

Вимоги сьогодення грунтуються на зростанні потреби у висококваліфікованих працівниках, тому важливе значення має розвиток кадрового потенціалу суспільства та держави. Важливе значення у цьому процесі має підвищення ролі управління професійним розвитком працівників, який покликаний професійно забезпечувати здійснення і1і реформування. Історичний досвід підтверджує, що країна сильна не лише економічним, військовим та науково-технічним потенціалом, але й своєю освітою.

Потреба в професійному розвитку персоналу визначається шляхом виявлення невідповідності, між наявними знаннями і навичками персоналу, і тими знаннями, які потрібні для досягнення поставлених організацією завдань. Мова йдеться про виявлення відмінностей між майбутніми та існуючими компетенціями. 